\title{
Turismo, espaço urbano e meio ambiente: análise do projeto de esgotamento sanitário do município de Maragogi $(\mathrm{AL})$
}

\author{
Tourism, urban space and environment: analysis of the \\ sewage project of the municipality of Maragogi (AL, Brazil)
}

\author{
Antônio de Padua Gomes D'Almeida Lins, Lindemberg Medeiros de Araujo, \\ Walter Matias Lima
}

\section{RESUMO}

Considerada como atividade socioeconômica importante e dinâmica, o turismo tem sido adotado como alternativa de desenvolvimento pelo governo de numerosos países, estados e municípios. Entretanto, além dos impactos positivos, essa atividade, pode causar graves problemas para os sistemas ecológicos, as paisagens e as comunidades que compõem os destinos. Portanto, é importante que se adote um planejamento a longo prazo que contemple, dentre outros aspectos, o saneamento ambiental, uma dimensão central do desenvolvimento sustentável. Para que isto ocorra, é importante que os projetos de saneamento sejam bem dimensionados e que haja ampla participação popular uma vez que os residentes conhecem muito bem o território local. O objetivo deste trabalho é analisar a implantação e operação do projeto de esgotamento sanitário de Maragogi, município do litoral norte de Alagoas. Maragogi é o segundo maior destino turístico de Alagoas, com quase 4.000 leitos, além de ser considerado pelo Ministério do Turismo um dos 65 Destinos Indutores do país. Para se atingir o objetivo deste trabalho, considerou-se importante analisar a visão de: a) técnicos que trabalham para o governo municipal; b) moradores, empreendedores e líderes locais que têm relação com o território; c) turistas. Para tanto, o estudo utilizou uma abordagem qualitativa e adotou como instrumentos de coleta de dados entrevistas abertas, entrevistas semiestruturadas, registro fotográfico, observação direta e exames de imagens remotas (Google Earth). O estudo identificou que o projeto de saneamento não contemplou todo o território do município de Maragogi, deixando várias fontes de esgoto fora do seu alcance. Graves problemas ambientais relacionados ao saneamento continuam ocorrendo, apesar da prefeitura utilizar como uma das suas estratégias de marketing dizer que o município é $100 \%$ saneado.

PALAVRAS-CHAVE: Turismo; Espaço Urbano; Meio Ambiente; Saneamento. 


\section{ABSTRACT}

Regarded as an important and dynamic socio-economic activity, tourism has been adopted as a development alternative by governments of many countries, states and municipalities. However, in addition to its positive impacts this activity can cause serious problems for ecological systems, landscapes and communities that make up the destinations. Therefore, it is important to adopt a long-term planning strategy that includes, among other things, environmental sanitation, as a central component of sustainable development. For this to happen, it is important that sanitation projects are well sized and that there is adequate popular participation as residents know the local territory. The objective of this study is to analyze the implementation and operation of the Maragogi's sewage project, in the north coast of Alagoas (Brazil). Maragogi is the second largest tourist destination of Alagoas, with almost 4,000 beds, in addition to being considered by the Ministry of Tourism as one of the country's 65 tourism attractor projects (Projeto Destinos Indutores). To achieve the objective of this work, it was considered important to analyze the views of: a) planners working for the municipal government; b) residents, entrepreneurs and local leaders; and c) tourists. Therefore, the study used a qualitative approach and adopted the followings data-collection instruments: open interviews, semi-structured interviews, photographic survey, direct observation, and examination of remote images (Google Earth). The study identified that the sanitation project did not include the entire territory of the municipality of Maragogi, leaving several sources of sewage out of the project's reach. Serious sanitationrelated environmental problems continue to occur, despite the local government continue to use as one of their marketing strategies the message that the municipality is $100 \%$ sanitized.

KEYWORDS: Tourism; Urban Space; Environment; Sanitation.

\section{Introdução}

Considerada como atividade socioeconômica importante e dinâmica, o turismo, com os processos de mudança que acarreta, pode alterar consideravelmente os sistemas ecológicos, bem como as paisagens e as comunidades que compõem as destinações (HALL; PAGE, 1999).

No processo de turistificação, as comunidades locais são seduzidas por promessas de desenvolvimento e geração de renda que muitas vezes não se materializam na realidade. Na prática, a maioria delas não se concretiza de forma significativa tendo em vista as limitações do mercado de trabalho formal associado ao turismo, normalmente devido baixo nível de escolaridade das populações locais das áreas subdesenvolvidas. De acordo com Araujo (2007), essa carência de capacitação profissional para trabalhar no turismo gera frustração quando as expectativas não são atendidas, causando mais exclusão social e não promovendo a tão almejada inclusão social, como no caso do estado de Alagoas. 
Alagoas é um estado, situado na região Nordeste do Brasil e que tem no turismo uma das suas principais atividades socioeconômicas. Alagoas tem mais de $200 \mathrm{~km}$ de litoral, com praias de areias brancas, entrecortadas por alguns trechos com falésias e emolduradas por vastos coqueirais. Além disso, em seu litoral está uma importante barreira de corais, que com sua rica fauna e flora, complementa os atrativos naturais costeiros.

Maragogi é um município, localizado no litoral norte de Alagoas, a 130 $\mathrm{km}$ de Maceió, capital do estado. Configura-se como o segundo polo receptor de turistas do estado e possui quase quatro mil leitos disponíveis em hotéis e pousadas de vários níveis, de resorts a pousadas rústicas administradas pelo próprio dono (SETUR, 2008). O município de Maragogi tem uma população de 28.749 habitantes (IBGE, 2010) e uma área de $334,047 \mathrm{~km}^{2}$ (IBGE, 2015).

Em meados da década de 1990, um financiamento conseguido pelo governo do Estado junto ao Programa de Ação para o Desenvolvimento do Turismo no Nordeste - Prodetur/NE, permitiu um amplo programa de construção e modernização do sistema de esgotamento sanitário da cidade de Maragogi com recursos advindos do Banco Interamericano de Desenvolvimento - BID (PROJETO TÉCNICO DO SISTEMA DE ESGOTAMENTO SANITÁRIO DO MUNICÍPIO DE MARAGOGI, ALAGOAS, 1997). O Prodetur/NE é um programa de crédito para o setor público (estados e municípios) que foi concebido para criar condições favoráveis à expansão e melhoria da qualidade da atividade turística na região Nordeste, ampliar e melhorar a infraestrutura básica, e para melhorar a qualidade de vida das populações residentes nas áreas beneficiadas.

Portanto, além de examinar a implantação de infraestrutura de saneamento como fator chave para um meio ambiente bem conservado, em conexão com o conceito de sustentabilidade, este trabalho também levanta questões relacionadas ao espaço habitado e à relação entre o desenvolvimento econômico e sua capacidade de degradar o meio ambiente (MARICATO, 2001). Este artigo tem como objetivo investigar os resultados da implantação do projeto de saneamento ambiental do município de Maragogi, para o meio ambiente, para a população local e para a atividade turística. O estudo utilizou uma abordagem qualitativa e adotou como instrumentos de coleta de dados entrevistas abertas e semiestruturadas, registro fotográfico, observação direta, e exames de imagens remotas (Google Earth).

\section{Turismo, espaço, paisagem e meio ambiente}

A Organização Mundial do Turismo (OMT apud SONAGLIO e FABBRIS, 2012, p. 81), define turismo como sendo "[...] as atividades das pessoas que viajam e permanecem em lugares fora de seu ambiente habitual por não mais de um ano consecutivo, para lazer, negócios e outros objetivos".

Outra definição é proposta por Lage e Milone (2000, p.26), 
O turismo é uma atividade socioeconômica, pois gera a produção de bens e serviços para o homem visando à satisfação de diversas necessidades básicas e secundárias. Em se tratando de uma manifestação voluntária decorrente da mudança ou do deslocamento humano temporário, envolve a indispensabilidade de componentes fundamentais como o transporte, o alojamento, a alimentação e, dependendo da motivação o entretenimento (lazer, atrações).

Para Sonaglio e Fabbris (2012, p. 81), o turismo é "um conjunto de atividades socioeconômicas, culturais, políticas e ecológicas que, visam favorecer as escolhas, necessidades e expectativas de turistas e residentes, de uma determinada localidade".

Observa-se, assim, que não existe uma definição unânime em relação ao conceito de turismo. No entanto, os autores comungam algumas ideias centrais, modificando apenas alguns aspectos em suas respectivas definições. A concepção de turismo adotada neste artigo é a de uma atividade na qual o indivíduo se desloca de seu local de origem para outro, por um espaço mais ou menos curto de tempo (mais de um dia e no máximo 365 dias), no qual se viaja por motivação pessoal das mais diversas como lazer, negócios, entre outros, por sua livre e espontânea vontade, e sem pretensão de auferir ganhos financeiros no lugar visitado.

Não se pode dissociar o turismo da noção de espaço, uma vez que a atividade consome espaço (CRUZ, 2002) e, consequentemente, o reorganiza. A relação entre turismo e espaço envolve outros conceitos como território e paisagem que ajudam a entender a construção do lugar como destinação turística. A maior parte dos destinos turísticos depende da paisagem como seu atrativo principal.

Segundo Santos (1997, p. 71), o espaço refere-se "[...] ao conjunto de objetos e relações que se realizariam sobre estes objetos; não entre estes especificamente, mas para os quais eles servem de intermediários". Aplicando o conceito de espaço adotado por Santos (1997) ao turismo, considera-se, então, que o espaço turístico diz respeito à presença e distribuição territorial dos mais variados atrativos turísticos que envolvem uma região; é o que Boullón (2002) chama de matéria prima do turismo, especificamente nas relações que a sociedade estabelece com um determinado lugar

Magalhães (2002) afirma que vários são os elementos que caracterizam e formam o espaço turístico, sendo eles responsáveis por alavancar a atividade turística de toda e qualquer região. De acordo com Palmeira (2007, p. 45) esses elementos também "[...] podem ser considerados como o próprio espaço turístico [...]" e os principais elementos que caracterizam e formam o espaço turístico são: os atrativos turísticos, os equipamentos e serviços indispensáveis ao desenvolvimento da atividade, a infraestrutura de apoio turístico, as instituições, a demanda e a comunidade. 
Avaliar a estética da qualidade das paisagens do espaço turístico é outro ponto que deve ser levado em consideração quando do planejamento e prática de qualquer modalidade de turismo em uma cidade, uma vez que há um forte vínculo entre turismo e lugar visitado. Cruz (2002, p. 109), a propósito, chama a atenção para o fato de que a "[...] paisagem é a primeira instância de contato do turista com o lugar visitado e por isso ela está no centro das atratividades dos lugares para o turismo".

Nesse sentido, Castro (2002, p. 132) entende que a paisagem traduz

o sentido de um meio em termos imediatamente acessíveis a visão, a audição e ao odor. Ela compreende uma lógica de identificação [...] a paisagem é o que se vê, e neste sentido ela é decorrência também do olhar que se constrói em parte da herança histórica de uma cultura e em parte como experiência individual.

Por outro lado, Stankoviv (apud SANCHO, 2001, p.201) afirma que "[...] o turismo é um consumidor específico dos recursos naturais, pois estes constituem parte importante para o desenvolvimento da atividade turística". No Brasil, o turismo desenvolve-se principalmente em áreas litorâneas e baseia-se no que é mais abundante, aspectos da natureza muito valorizados pelo turismo, isto é, sol, praias e o mar, imbricados com o restante do patrimônio natural e a paisagem (YÁZIGI, 2003). O intenso processo de produção e consumo do espaço turístico nas regiões costeiras brasileiras vem se agravando de forma significativa e tem gerado uma grande preocupação não só quanto aos aspectos ambientais, mas também sociais e institucionais de desenvolvimento.

Por sua abrangência e complexidade, o turismo pode alterar consideravelmente os sistemas ecológicos, bem como as paisagens e as comunidades que compõem as destinações (HALL; PAGE, 1999). Grande parte dos ecossistemas, sobretudo os litorâneos, não resiste aos impactos resultantes do turismo. A supressão da vegetação nativa, o aterro em áreas alagáveis e mangues, a destruição de dunas e restingas são alguns dos impactos ambientais frequentes nas regiões tropicais. A perda da diversidade nesses habitats compromete, algumas vezes irreversivelmente, o patrimônio natural dos lugares (ARAUJO, 2007).

\section{Os impactos econômicos e socioculturais do turismo}

Segundo a Organização Mundial do Turismo, a atividade turística é um dos setores da economia que mais cresce no mundo. Ela movimenta cerca de três trilhões e quinhentos bilhões de dólares americanos anualmente e apenas na década de 1990 expandiu sua atividade em 57\% (OMT, 2004).

O turismo provoca impactos econômicos e culturais resultantes da interação entre a atividade, os turistas, as comunidades locais e os meios receptores. Segundo Ruschmann (1993), os impactos do turismo referem-se a uma ampla gama de modificações ou sequência de eventos, provocados pelo processo de desenvolvimento turístico nas localidades receptoras. 
Inegavelmente, o turismo é uma importante fonte de crescimento e desenvolvimento para a economia de uma região e está inserido na lógica capitalista em sua fase globalizada. O processo de turistificação demanda uma infraestrutura mínima para implantação de equipamentos como hotéis e pousadas. Essa implantação gera emprego e renda, além de tributos e diversificação da economia com a necessidade de investimento em outros equipamentos para suprir a demanda dos turistas, como bares, restaurantes, locadoras de veículos, agências de turismo entre outros. Além disso, o turismo também pode proporcionar conservação do patrimônio local, reafirmando a identidade cultural do lugar e proporcionando um intercâmbio cultural com os visitantes.

No entanto, o turismo também gera impactos negativos. Nem todas as suas formas culminam em um desenvolvimento que permita retorno econômico e social para as comunidades envolvidas. Na prática a maioria das expectativas positivas relacionadas ao turismo não se materializa de forma significativa. Boa parte dos grupos estrangeiros que aportam nas destinações turísticas traz do país natal mão-de-obra qualificada, deixando para os nativos os cargos que exigem menos qualificação. Segundo Araujo (2007), a carência de capacitação de mão de obra para um trabalho novo gera frustração quando as expectativas não são atendidas, causando mais exclusão social e não promovendo a tão almejada inclusão.

Outros problemas graves também podem ocorrer com o aumento da população residente e sazonal, decorrentes da falta de infraestrutura básica e da perda da comodidade dos habitantes. Esse incremento populacional gera especulação imobiliária, outra face desigual da globalização onde grandes grupos, muitas vezes estrangeiros, se apropriam do território e a população local é impelida para áreas marginais por não poder pagar 0 preço da terra que anteriormente as pertencia, às vezes por gerações. Esse processo chamado de "gentrificação" também favorece a degradação ambiental uma vez que essa população deslocada acaba ocupando áreas frágeis, como mangues e encostas, e não tendo meios para construir de forma adequada contribuirão ainda mais para a degradação ambiental.

Assim, com o desenvolvimento do turismo nas destinações a desigualdade social tende a se agravar e a existência de contingentes populacionais que estão à margem do processo social multiplica e aprofunda os conflitos sociais e a deterioração da qualidade de vida no território, aumentando a exclusão desses indivíduos que não conseguem se incluir no sistema produtivo. Com o turismo de massa, aumentam ainda consideravelmente os desvios sociais com o incremento do tráfico de drogas, prostituição, crimes, etc.

Ruschmann (2002, p.37) afirma que,

Os impactos do desenvolvimento turístico sobre o patrimônio natural e cultural são percebidos local, regional, nacional e internacionalmente. A intensidade dos impactos, tanto positivos como negativos, pode apresentar-se nesses diferentes níveis. Em alguns casos, os impactos não são relevantes e, em outros, comprometem as condições de vida ou a atratividade das localidades turísticas. 
Assim, cabe ao poder público e até mesmo à comunidade local tomar os cuidados necessários, para que estes efeitos negativos possam ser sanados ou minimizados. Em outras palavras, cabe a todos os envolvidos no processo de desenvolvimento turístico o comprometimento com a conservação do patrimônio natural e cultural do território que está sendo explorado pelo turismo.

\section{Desenvolvimento sustentável do turismo}

Há pouco tempo atrás, a ideia que se tinha em relação ao desenvolvimento sustentável do turismo era tão somente voltada à proteção ao meio ambiente, de modo especial junto aos países desenvolvidos (RUSCHMANN; WIDMER, 2001). Diferentemente do passado, 0 desenvolvimento sustentável da atividade turística na atualidade não só está vinculada à importância da conservação e proteção do meio ambiente como também a todos os recursos e critérios não só sociais como também econômicos e culturais, conforme propõe Töpfer (2002).

De acordo com a OMT (apud KÖRÖSSY, 2008, p.63), o desenvolvimento sustentável do turismo se dá a partir do atendimento "[...] das necessidades dos turistas de hoje e das regiões receptoras, ao mesmo tempo em que protege e amplia as oportunidades para o futuro". Partindo desse pressuposto, Pires (2002, p. 117), afirma que o conceito de turismo sustentável se fundamenta "[...] no próprio princípio universal de sustentabilidade, que implica a necessidade de conservar os recursos para que as futuras gerações possam utilizá-los e desfrutá-los com os mesmos direitos das gerações atuais".

Ao seguir esta mesma linha de entendimento, Ruschmann (2008) chama a atenção para o fato de que o turismo sustentável deve abranger a existência de turistas cada vez mais responsáveis, de modo que suas ações junto às comunidades receptoras possam ser verdadeiramente equilibradas nos campos sociais, culturais e ambientais.

Para isto, é de fundamental importância o planejamento da atividade turística e que esta inclua a participação dos grupos e agentes que são afetados pelas intervenções nas áreas turistificadas (ARAUJO, 2007). Ainda segundo Beni (2006, p.63)

\footnotetext{
O modelo de gestão participativa pode trabalhar não apenas em prol da integração entre as diversas esferas em que atuam os agentes decisores, mas na democratização da informação e dados para permitir a construção de uma nova forma de agir, fora dos velhos paradigmas do assistencialismo, paternalismo, utilizando um planejamento participativo, integrado e, mais importante, convergente com os anseios da população, fazendo às vezes de multiplicador do conhecimento, de histórias e identidades locais.
}

A participação no planejamento tem o potencial de aumentar os benefícios do turismo, por levar em consideração a opinião de vários atores sociais que serão atingidos, positiva e negativamente, pelo turismo. É 
inoportuno pensar em desenvolvimento sustentável sem pensar na inclusão de todos os interessados no planejamento, implantação e gestão das ações que se pretende implantar, mesmo que isso exija mais tempo de planejamento.

Portanto, cabe a todos os envolvidos no processo de planejamento e desenvolvimento das atividades turísticas voltarem-se às reais preocupações que devem ser levadas em consideração quando do planejamento e implementação de políticas públicas de desenvolvimento turístico, incluindo-se neste rol os próprios turistas que devem ter em mente a importância da preservação dos mais variados recursos naturais e patrimoniais das cidades que visitam, os empresários dos mais variados ramos, as organizações do terceiro setor, enfim, todos aqueles que fazem acontecer o turismo. Esta não é uma tarefa fácil, uma vez que o turismo, por ser uma atividade econômica e vender uma mercadoria (serviço), está baseado no conflito capital e trabalho.

\section{A importância do saneamento ambiental}

O crescimento populacional e a ocupação desordenada nos aglomerados urbanos fazem com que a degradação ambiental tenha se tornado um grande problema ambiental no Brasil. O saneamento surge como um importante vetor de controle dessa degradação, desde que implantado, operado e gerido de forma adequada.

A quantidade de água necessária às atividades da humanidade aumenta geometricamente ano após ano. Entretanto, a quantidade de água doce disponível nos mananciais em todo mundo vem diminuindo ou se extinguido de maneira grave, devido às mudanças climáticas ou principalmente por causa dos problemas ambientais resultantes de um uso perdulário dos recursos hídricos.

Uma importante forma de preservar a água é o investimento em sistemas de saneamento e no tratamento do esgoto sanitário coletado através de uma rede e depositado em uma estação que o depure no menor espaço de tempo possível. Segundo Toneto Junior (2004), o efluente recuperado por esses sistemas e pode ser devolvido aos corpos de água ou (re)usado das mais diversas formas. Ainda de acordo com Toneto Junior (2004, p.31), "[...] essas alternativas contribuem para a diminuição do uso da água potável, sendo uma boa forma de garantir a saúde, preservar o meio ambiente e garantir a sustentabilidade do território".

Foi entre as décadas de 1970 e 1980 que os investimentos em saneamento básico no Brasil atingiram seu ápice. Foi nessa época que, segundo Soares et al. (2002), se consolidou o Plano Nacional de Saneamento (Planasa), que deu ênfase aos sistemas de abastecimento de água em detrimento aos de coleta e tratamento de esgoto que se mantêm em níveis inaceitáveis, sobretudo nas regiões mais pobres do país. Segundo - Sistema Nacional de Informações de Saneamento - SNIS (2014), mais de $50 \%$ do esgoto produzido no Brasil ainda não é coletado (Quadro 1). Além disso, os dados confirmam a disparidade entre regiões. Enquanto na região Norte do Brasil apenas 7,9\% do esgoto tem coleta, na região Sudeste esse 
número sobe a $78,3 \%$. A evolução no tratamento também é significativa e neste dado os números se invertem. As regiões que mais coletam, tratam menos, devido ao volume superior de esgoto e consequentemente uma demanda bem maior de investimentos.

Quadro 1: Coleta e tratamento de esgoto por município (\%) e por região do Brasil 2014 Chart 1: Collect and treatment of sewage for municipality (\%) and for region of Brazil 2014

\begin{tabular}{|c|c|c|c|c|}
\hline \multicolumn{5}{|c|}{$\begin{array}{l}\text { COLETA E TRATAMENTO DE ESGOTOS POR MUNICIPIOS (\%) E POR REGIÃO DO } \\
\text { BRASIL } 2014\end{array}$} \\
\hline \multirow[t]{2}{*}{ REGIÃO } & \multicolumn{2}{|c|}{$\begin{array}{l}\text { ÍNDICE DE ATENDIMENTO / } \\
\text { COLETA COM REDE \% }\end{array}$} & \multirow{2}{*}{$\begin{array}{c}\text { ÍNDICE DE } \\
\text { TRATAMENTO } \\
\text { TOTAL }\end{array}$} & \multirow{2}{*}{$\begin{array}{c}\text { SEM COLETA } \\
\text { TOTAL }\end{array}$} \\
\hline & URBANO & TOTAL & & \\
\hline NORTE & 9,9 & 7,9 & 78,2 & 92,1 \\
\hline NORDESTE & 31,1 & 23,8 & 78,5 & 76,2 \\
\hline SUDESTE & 83,3 & 78,3 & 65,4 & 21,7 \\
\hline SUL & 44,4 & 38,1 & 84,1 & 61,4 \\
\hline CENTRO OESTE & 51,7 & 46,9 & 91,1 & 53,1 \\
\hline BRASIL & 57,6 & 49,8 & 70,9 & 50,2 \\
\hline
\end{tabular}

Quando não existe rede coletora de esgoto, ou outra forma segura de destinar os dejetos domésticos como as fossas sépticas, os dejetos ou contaminam o solo ou os corpos d'água, deixando um rastro de degradação que também leva à veiculação de doenças dos mais diversos tipos, o que conflita com os objetivos de desenvolvimento turístico.

Para Maricato (2001, p.40),

O destino das águas servidas e do esgoto, assim como de boa parte do lixo sólido produzido, fica evidente no desastroso comprometimento das redes hídricas, dos mananciais de água, das praias, dos mangues ou de qualquer outra localização nos arredores das cidades que não seja de interesse do mercado imobiliário.

Esses problemas trazem graves consequências para a balneabilidade de lugares turísticos como Maragogi. Segundo o Instituto do Meio Ambiente de Alagoas (IMA) o termo balneabilidade é empregado ao indicador que mede as condições sanitárias das águas destinadas a recreação de contato primário. Quando em uma amostra for constatada a presença da bactéria Escherichia coli significa dizer que a mesma está contaminada. Esta bactéria vive em esgotos e dejetos humanos e de animais e é encontrada na água ou solo contaminado, sendo o indicador de contaminação mais usado para identificar a degradação em corpos de água.

Segundo a portaria no 2914 de 2011, do Ministério da Saúde, que dispõe sobre os procedimentos de controle e de vigilância da qualidade da água para consumo humano e seu padrão de potabilidade, as amostras não 
podem passar de 1000 NMp (Número Mais provável) de coliformes fecais a cada 100 mililitros de água colhida. Quando passa de $1000 \mathrm{NMp} / 100 \mathrm{ml} \mathrm{a}$ praia é considerada imprópria para recreação de contato primário, podendo transmitir uma série de doenças de veiculação hídrica como hepatite, diarreia, cólera e febre tifoide.

Dessa forma, pode-se concluir que o saneamento é um importante vetor de sustentabilidade. Quando bem implantada e gerida, uma rede coletora pode melhorar bastante a qualidade ambiental da localidade, com impactos positivos para a população residente, representando fator dos mais positivos para o desenvolvimento do turismo, principalmente quando a destinação tem por base o turismo de "sol e mar", no qual a qualidade das águas usadas para recreação é um dos mais importantes fatores de atratividade.

\section{Metodologia}

O trabalho inclui um estudo de caso do município de Maragogi. Ressalta-se que o estudo de caso é empregado em diversos campos da ciência. Trata-se de uma pesquisa detalhada sobre um ou mais objetos a serem investigados. O estudo de caso visa refletir sobre um conjunto de dados para posteriormente descrever com maior profundidade o objeto de estudo (MASCARENHAS, 2012). Com a realização dessa etapa (do estudo de caso), foram conduzidas entrevistas semiestruturadas, por meio de questionário com perguntas abertas e fechadas, junto aos stakeholders que interagem na área estudada, como a população local e os turistas. Marconi e Lakatos (2010) ressaltam que a entrevista aberta é um meio utilizado quando da realização de pesquisas afim de que os entrevistados possam expressar o que pensam, acreditam, sentem e compreendem em relação ao objeto de estudo. A entrevista aberta é a melhor forma de capturar as informações que nem sempre são possíveis perceber em entrevistas estruturadas. Já para os empreendedores e representantes do poder público, também foram utilizadas entrevistas abertas, só que nesse caso as entrevistas foram gravadas e posteriormente transcritas

Para construção das entrevistas deste trabalho, fez-se a opção pela pesquisa com abordagem qualitativa, com amostragem não probabilística, tendo-se adotado amostragem intencional (MINAYO, 2007; REIS, 2008). Este tipo de abordagem possibilita ao pesquisador uma diversidade de interpretações, à medida que pode melhor explica os fenômenos que se encontram envoltos por complexas situações. Por ser do tipo semiestruturada, o foco da entrevista, que são o saneamento, o meio ambiente e o turismo, conduz o entrevistado a falar sobre esses temas. Portanto, no que diz respeito à pesquisa semiestruturadas, Hitchook e Hughes (apud NEVES, 2014), revelam que este tipo de entrevista "[...] confere a abertura necessária para que o entrevistado complemente suas respostas mostrando-se sensível ao contexto de interação em que a mesma ocorre". Desta forma, foram inseridos complementos às respostas diretas, para ensejar conversas informais com base nas quais foram colhidas informações importantes acerca do território e suas peculiaridades, sobretudo nas entrevistas com a população local. 
A pesquisa de campo foi realizada no período de julho do ano de 2014 a julho de 2015, com visitas mensais à área de estudo, com permanência média de três dias. Após análise dos aportes teóricos e do projeto disponibilizado pela CASAL, o passo subsequente foi conhecer a região em que o projeto estava inserido, para a definição do recorte de estudo dentro da área do município de Maragogi. Foi definido então, que seria considerada como área de pesquisa, a região composta pelas bacias hidrográficas dos principais rios que cortam o município, Salgado, Maragogi dos Paus e Persinunga, além dos aglomerados populacionais formados pelo centro urbano e pelos povoados de São Bento, Barra Grande, Ponta do Mangue e Peroba, situados na franja litorânea à margem direita da AL-101Norte.

As entrevistas foram realizadas com a população local no centro e nos povoados acima mencionados com 31 questionários aplicados por amostragem. Aos turistas, brasileiros e estrangeiros, foram aplicados 30 questionários nos hotéis, praias e equipamentos turísticos na cidade. As entrevistas com os empreendedores e gestores públicos locais foram feitas depois de uma escolha cautelosa de quem seria importante para a pesquisa em um determinado momento e para se obter uma informação específica, mas quase sempre eram descortinadas novas informações que levavam a mais investigações. Convém salientar que as transcrições, ou partes delas, quando aparecem no texto, são identificadas apenas pelo tipo do entrevistado seguido de uma letra, juntamente com a data (mês e ano) em que foi realizada a entrevista. Esse cuidado se faz necessário, uma vez que o sigilo dos entrevistados está garantido pelo Termo de Consentimento Livre e Esclarecido exigido pelo Comitê de Ética.

Os levantamentos de dados estatísticos e indicadores ambientais foram realizados junto ao Instituto do Meio Ambiente de Alagoas - IMA, Companhia de Saneamento de Alagoas - CASAL, Secretaria Municipal de Turismo de Maragogi, Secretaria Municipal de Meio Ambiente de Maragogi, Secretaria Estadual de Turismo - Setur, Instituto do Patrimônio Histórico Nacional - IPHAN e Instituto Chico Mendes de Conservação da Biodiversidade - ICMBio.

A observação direta, com o registro fotográfico de diversas áreas do município de Maragogi, foi outra técnica empregada para coleta de dados. Para complementar o levantamento de dados também foram usadas imagens remotas do Google Earth.

\section{Caracterização da área de estudo: o município de Maragogi}

O município de Maragogi, localizado na porção Norte-Nordeste do Estado de Alagoas, limita-se ao Norte com o município de São José da Coroa Grande, no Estado de Pernambuco; ao Sul com o município de Japaratinga; a Leste com o Oceano Atlântico; e a Oeste com os municípios de Jacuípe e Porto Calvo em Alagoas.

De acordo com o IBGE (2015), o município ocupa uma área de $334,047 \mathrm{Km}^{2}$, o que corresponde a aproximadamente $1,20 \%$ de Alagoas, com altitudes que variam "[...] entre $100 \mathrm{~m}$, nos morros a noroeste e $5 \mathrm{~m}$ na planície costeira" (MONTE; SANTOS, 2015, p.5). Sua temperatura mínima é 
de $18^{\circ} \mathrm{C}$ e máxima de $36^{\circ} \mathrm{C}$ e sua precipitação anual "[...] superior a 1.400 $\mathrm{mm}$, concentrada de abril a julho, seu clima, segundo a classificação Thornthwaite, é megatérmico subúmido com excedente hídrico no inverno e deficiência no verão" (ENCICLOPÉDIA DOS MUNICÍPIOS ALAGOANOS, 2010).

Com 28.749 habitantes, $18.625(64,78 \%)$ encontram-se na área urbana e $10.124(35,22 \%)$ na área rural com uma densidade demográfica de 86,06 habitantes/ $/ \mathrm{Km}^{2}$ (IBGE, 2010).

Entre as principais atividades econômicas do município estão canade-açúcar, coco, feijão, laranja, mandioca, maracujá, milho, apicultura, ovino caprinocultura e de serviços, segundo Barreto et al. (2006) e Lima e Lopes (2014).

A pesca também é uma atividade importante para o município, todavia, "[...] apesar de ser um município de origem agrária" [...], o setor de serviços passou a ser o principal responsável pela composição do Produto Interno Bruto (PIB) do município, com o turismo ocupando atualmente importante posição na economia de Maragogi (KASPARY, 2012).

A área selecionada como objeto de estudo (Figura 1), centra-se na faixa territorial litorânea do município de Maragogi, onde atualmente ocorre um importante processo de transformação socioespacial desencadeado pelo turismo. Essa faixa territorial margeia o Oceano Atlântico, além de compreender a zona urbana do Distrito de São Bento (divisa com o município de Japaratinga, Alagoas), até Peroba (divisa de São José da Coroa Grande, no Estado de Pernambuco), o que corresponde à cerca de $21 \mathrm{~km}$ lineares. De acordo com Monte e Santos (2015), Maragogi conta com as bacias hidrográficas dos rios Salgado, Maragogi, dos Paus, e Persinunga.

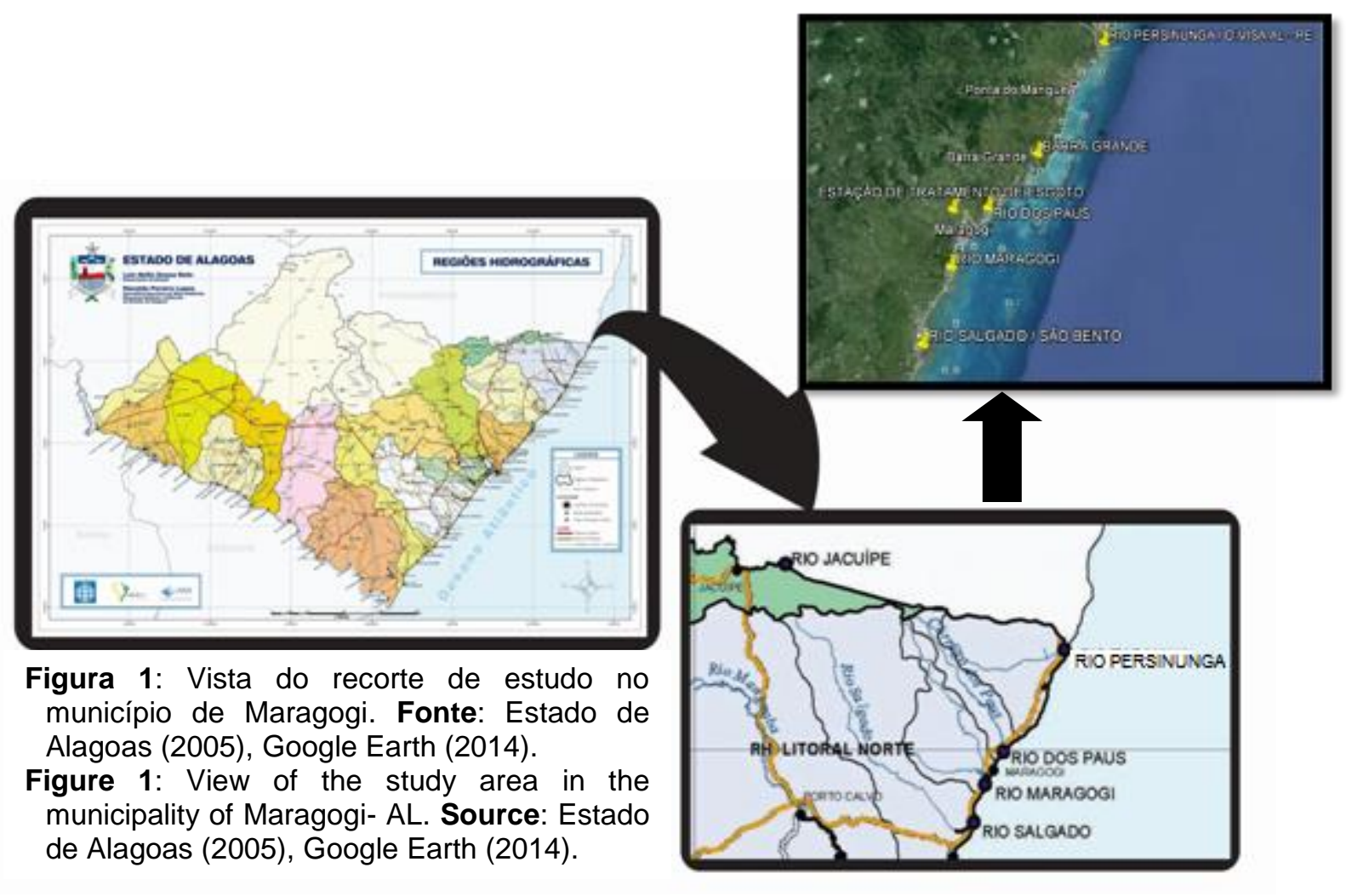


A escolha do município em questão para este estudo se deu por duas razões específicas. A primeira, por ser um destino turístico cujo espaço é vendido comercialmente como $100 \%$ saneado, o que na verdade não é, fato que foi comprovado através de pesquisas conduzidas in loco que serão apresentadas neste trabalho. A segunda razão está diretamente vinculada aos seus mais diversos atrativos turísticos naturais e culturais, a exemplo de suas belas praias, piscinas naturais, sítios arqueológicos, entre outros, o que exige que o espaço esteja devidamente protegido para bem receber aquele que procura essa destinação em busca de lazer.

\section{Os adensamentos populacionais do município de Maragogi}

A sede municipal de Maragogi situa-se na praia homônima. Nesta parte do município está concentrada grande parte da infraestrutura turística, uma vez que possui o comércio, uma orla que ainda se encontra em processo de requalificação e diversos serviços, a exemplo de bares e restaurantes, agências bancárias, a sede do corpo de Bombeiros e da Policia Militar, a Colônia de Pescadores, as secretarias municipais, Câmara de Vereadores e uma importante variedade de equipamentos de hospedagem como pousadas e hotéis a citar: Hotel Salinas do Maragogi, Hotel Areais Belas, Pousada Mar e Luz, entre outros.

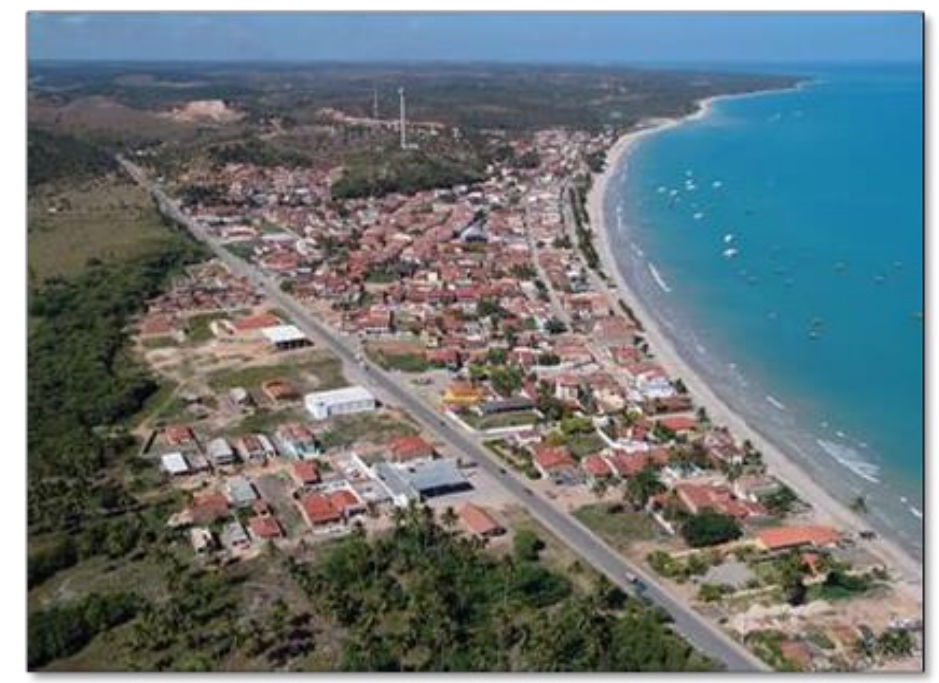

Figura 2: Vista aérea do município de Maragogi em sua porção Sudoeste.

Fonte: Caribe Nordestino (2015).

Figure 2: Air view of Maragogi's municipality in Southwest portion.

Source: Caribe Nordestino (2015).

Situado no extremo sul do município na divisa com Japaratinga, São Bento é banhado pelo rio Salgado. Apesar de ser o mais antigo, São Bento é o povoado menos transformado pelo tempo, sobretudo se comparado ao centro urbano e aos povoados mais ao Norte. A percepção espacial que se tem ao se caminhar pelo povoado é bem diferente da experiência do resto do litoral. Existem inúmeros terrenos desocupados à beira mar e casas rústicas de pescadores ou com arquitetura simples de duas águas e antigas. A avenida à beira mar, como quase todas, ainda é de areia ou barro, quase não existe calçamento e asfalto apenas na $\mathrm{AL}-101-$ Norte. $\mathrm{O}$ ar é bucólico e 
os moradores ficam nas calçadas conversando como em pequenas localidades interioranas.

O Distrito ou Povoado de Barra Grande está localizado a aproximadamente três quilômetros do centro da cidade de Maragogi e possui uma característica bastante peculiar. A rua da Praia, como é conhecida sua avenida à beira-mar, não fica às margens da faixa litorânea, mas sim aos fundos das casas e mansões, geralmente de veraneio, que se debruçam sobre o mar no efeito popularmente chamado de "pé na areia".

Existe uma segregação espacial clara nesse formato de orla, sendo sofrida pelos moradores originais da localidade, sobretudo os antigos pescadores. As grandes mansões de forasteiros foram se instalando e tomando conta do espaço antes reservado a eles, obstruindo inclusive o acesso ao mar que hoje só pode ser feito por algumas ruas. Esse processo de gentrificação social, é muito marcante neste distrito, uma vez que claramente existe uma diferenciação espacial entre a zona dos morros situados do outro lado da AL-101-Norte, a franja até detrás da rua da Praia e esta propriamente dita.

Já os povoados de Peroba e Ponta do Mangue estão a $12 \mathrm{~km}$ da sede do município, sendo, portanto, os mais distantes do centro urbano do município. Situado entre os povoados de Barra Grande e o município de São José da Coroa Grande (PE) é banhado pelo rio Persinunga, na divisa de Alagoas e Pernambuco. Segundo relatos dos nativos, nos primórdios da ocupação de seu território, a região já foi local de veraneio dos próprios moradores abastados de Maragogi. Na fala de um antigo morador (morador $\left.A^{1}\right)$,

Há uns 20 anos isso aqui era tudo mato e coqueiro. As poucas casas que tinham eram ou da gente ou do povo da cidade mesmo, lá de Maragogi, que vinham passar o final de semana. Hoje, nós nem podemos chegar à praia direito por causa dos condomínios que tomaram tudo por aqui e está cheio de gente estranha e gringos. Muita coisa mudou por aqui e tudo ficou muito caro depois que esse povo chegou (julho de 2015).

Hoje, predominam no lugar os condomínios horizontais de alto padrão, autodenominados "privês", e casas de veraneio. A presença destes empreendimentos com seus muros altos e portões sempre fechados, denotam a segregação espacial que os moradores nativos sofrem com a ocupação do lugar, sobretudo para as atividades de cunho turístico. Vem ocorrendo a apropriação da franja litorânea por "estrangeiros" à localidade. Esses privês e condomínios privatizam as praias e dificultam muito o acesso da população, sendo alvo inclusive de ações no Ministério Público Municipal para que estes empreendimentos abram acessos à praia, sobretudo no povoado Ponta dos Mangues. 


\section{Meios de hospedagem e atrativos turísticos}

Segundo Gonçalves (2001), a instalação do Resort Salinas do Maragogi, em 1989, representou o início da projeção turística do município. Embora não tenha sido o primeiro meio de hospedagem a se instalar na localidade, pois já existiam algumas pousadas, foi o empreendimento que mais trabalhou a divulgação da destinação junto às grandes operadoras de turismo nacionais. Anteriormente, o fluxo turístico era formado em sua maioria pelos moradores dos municípios próximos, de Alagoas e de Pernambuco, que costumavam veranear na localidade ou turistas alocêntricos, de vários lugares do Brasil.

Foi justamente a partir dele que outros hotéis e resorts, pousadas, chalés, condomínios e privês foram sendo construídos, o que na atualidade perfaz um quantitativo de 69 unidades, totalizando assim 4.016 leitos.

Tabela 1: Relação dos tipos, quantidades, número de UHs e leitos de hospedagem disponibilizados aos turistas em Maragogi.

Table 1: List of the types, amounts, number of UHs and hosting beds available to tourists in Maragogi.

\begin{tabular}{lccc}
\hline \multicolumn{1}{c}{ TIPO DE HOSPEDAGEM } & QUANTIDADE & $\begin{array}{c}\text { NÚMERO DE } \\
\text { UHs }\end{array}$ & LEITOS \\
\hline Hotel/Resorts & 8 & 757 & 1.422 \\
Chalés & 5 & 46 & 174 \\
Pousada & 42 & 542 & 1.407 \\
Condomínios & 2 & 7 & 21 \\
Privês & 12 & 142 & 992 \\
TOTAL & 69 & 1.484 & 4.016 \\
\hline
\end{tabular}

Fonte: Secretaria de Turismo de Maragogi (2014).

Source: Secretaria de Turismo de Maragogi (2014).

Incluído entre os 65 Destinos Indutores do turismo no Brasil pelo MTur (2011), e segundo destino turístico mais procurado do estado de Alagoas, Maragogi tem como principal atrativo as piscinas naturais costeiras (Figura 3 ), formadas pelos recifes de coral, conhecidas como galés. Amplamente divulgadas em âmbito nacional e internacional, as galés estão inseridas na APA Costa dos Corais e tem sua visitação razoavelmente normatizada, controlada e fiscalizada pelo Instituto Chico Mendes de Conservação da Biodiversidade (ICMBio).

Além das piscinas naturais, existem outras opções e pode-se encontrar ofertas de passeios para visitar desde comunidades rurais e trilhas, sítios históricos, mergulhos em áreas de naufrágios, passeios de bicicleta e até saídas noturnas para acompanhar pescadores no exercício da sua profissão.

O turismo rural é mais uma opção, que vem mostrando potencial de exploração para a destinação. A iniciativa surgiu com a instalação de um grande investimento privado, o Marrecas Hotel Fazenda, do mesmo grupo que controla o Hotel Salinas e outros empreendimentos na cidade, que oferece hospedagem na área preservada de um velho engenho de açúcar, com diversas opções de lazer (VISITEMARAGOGI.COM, 2015). 


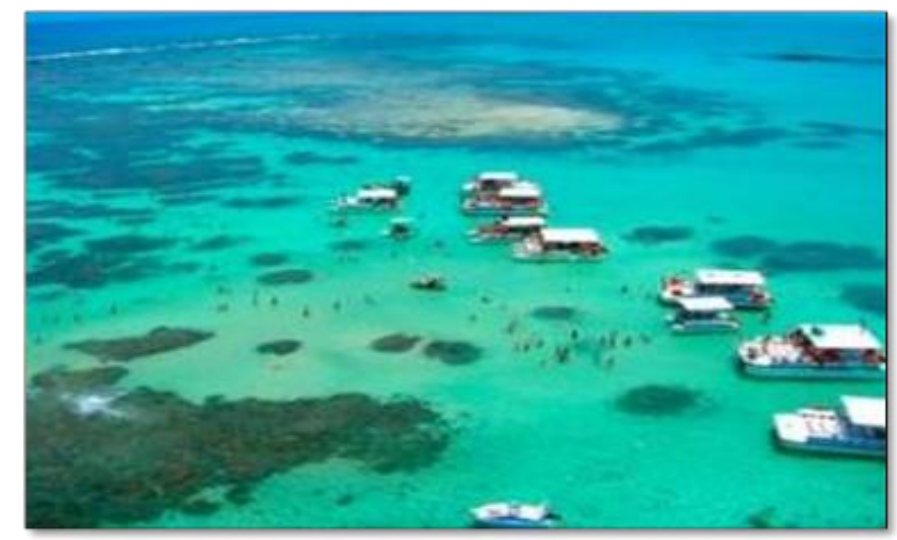

Figura 3: Piscina natural - Galés de Maragogi. Fonte: hoteisbeiramar.com.br (2015).

Figure 3: Natural Pool - Galés of Maragogi.

Source: hoteisbeiramar.com.br (2015).

Quadro 2: Principais atrações de Maragogi

Chart 2: Maragogi's main atractions

\begin{tabular}{|c|c|}
\hline Praias & $\begin{array}{c}\text { Central, Barra Grande, São Bento, Camacho, Pontal de Maragogi, Porto de } \\
\text { Galés, Burgalhau, Xaréu, Antunes, Ponta de Mangue e Peroba. }\end{array}$ \\
\hline Morros & Cruzeiro (no centro da cidade) e Colinas de São Bento. \\
\hline Piscinas naturais & Galés, Barra Grande, Taocas, Taoquinhas, Picões e Cabeços. \\
\hline Rios & Salgado, Maragogi, dos Paus e Persinunga. \\
\hline Festas e eventos & $\begin{array}{r}\text { Nossa Senhora da Guia (jan.), Carnaval (fev. ou mar.), Santo Antonio e São } \\
\text { Pedro (jun.), Festa da Mariscada (nov.). }\end{array}$ \\
\hline $\begin{array}{c}\text { Monumentos e } \\
\text { ruínas }\end{array}$ & $\begin{array}{r}\text { Ruínas da igreja da colina de São Bento, Igreja de nossa Senhora da Guia, } \\
\text { Igreja do Engenho junco, Capelinha de Santa Luzia. }\end{array}$ \\
\hline Artesanato & $\begin{array}{c}\text { Artefatos (esculturas e móveis) produzidos a partir de troncos de jaqueira e de } \\
\text { coqueiro, traçados da palha de bananeira e do ouricuri, rendas e bordados, } \\
\text { artefatos produzidos a partir da casca de coco e de cochas marinhas. }\end{array}$ \\
\hline Folclore & Pastoril, quadrilhas, cavalhadas, coco-de-roda, samba de matuto. \\
\hline Culinária & $\begin{array}{c}\text { Peixes, e crustáceos em várias opções, Bolinho de goma (povolo de São } \\
\text { Bento) e pratos da zona rural (carneiro, buchada, sarapatel, pirão, etc.) }\end{array}$ \\
\hline Passeios & $\begin{array}{c}\text { Trilhas na Mata Atlântica, visitas ao povoado de São Bento, Peroba e aos } \\
\text { municípios de Japaratinga, São Miguel dos Milagres e Porto de Pedras feitos } \\
\text { em bugres, passeios de bicicleta, mergulho e visita às Galés }\end{array}$ \\
\hline
\end{tabular}

Fonte: Adaptado de Barros (2010); visitemaragogi.com (2015).

Source: Adapted by Barros (2010); visitemaragogi.com (2015).

\section{Análise do projeto de esgotamento sanitário no município de Maragogi}

Após os primeiros turistas alocêntricos na década de 1970, Maragogi começou a despontar para sua vocação turística com a instalação dos primeiros hotéis de grande porte como o Resort Salinas em 1989. O município já possuía graves problemas em seus sistemas ecológicos, nas paisagens e nas comunidades. Desde a ocupação desordenada no centro urbano e alguns povoados como Barra Grande até o fechamento dos acessos a praia na parte Norte do município, seu território passou por significativas transformações e crescimento populacional que vieram a comprometer seu meio ambiente.

Segundo Hall e Page (2002) as áreas turísticas são dinâmicas e seu processo de evolução precisa de um planejamento para que não apenas cresça, mas também se desenvolva, gerando benefícios e renda para a 
população local, em contraponto ao simples repatriamento de lucros à matriz ou empregados vindos de fora, alheios ao lugar e à realidade local.

Maragogi, um destino de "sol e mar", precisava se preocupar com seu meio ambiente natural, uma vez que a recreação de contato primário em suas águas e a abundante oferta de dias ensolarados era e ainda é seu principal atrativo e símbolo no mercado turístico. As paisagens, que para Cruz (2002) são "[...] um dos principais focos de atratividade do lugar uma vez que é a primeira instância de contato com o turista" [...], precisavam estar disponíveis da forma como eram vendidas em campanhas de marketing: preservadas e paradisíacas, o que não tem sido o caso de Maragogi.

Em face ao cenário acima exposto, considerando Maragogi como área prioritária e em processo de turistificação e não possuindo sistema coletivo efetivo de esgotamento sanitário, o governo do Estado de Alagoas, através da sua Secretaria de Planejamento e Desenvolvimento - Seplandes, conseguiu junto ao Prodetur/NE, então em sua primeira fase, um financiamento com recursos advindos do BID para implementação de um projeto de saneamento para Maragogi. A concepção do Projeto Original (1995), para coleta, afastamento, tratamento e destinação final dos dejetos produzidos na área urbana da cidade de Maragogi e no povoado de Barra Grande, foi desenvolvida a partir de informações consolidadas entre a Contratante, - Companhia de Saneamento de Alagoas - CASAL, a Sistema PRI, empresa contratada, e a Unidade Executora Estadual de Alagoas, Seplandes, instituição responsável por toda implantação do projeto.

No diagnóstico inicial de 1995, e nas revisões subsequentes até a final em junho de 1997, foram identificadas as principais características do município, como localização geográfica, acessos, relevo, hidrografia, clima, pluviometria, aspectos econômicos, abastecimento de água, esgotamento sanitário, energia elétrica, sistemas viário e de transporte, comunicação, saúde e disponibilidade de insumos, este último relacionado à mão-de-obra para construção civil e disponibilidade de material para obra. No entanto, o conteúdo do projeto não fazia jus ao largo e completo escopo de variáveis do diagnóstico.

Outro dado chama a atenção no projeto. Por não estarem inseridos na área de cobertura da CASAL, os povoados de São Bento, densamente povoado, e Peroba, que na época possuía apenas algumas casas de veraneio esparsas, não foram contemplados com 0 programa de esgotamento. As duas localidades não possuíam, e ainda não possuem, rede de abastecimento de água da CASAL, mas sim, sistemas autônomos, os quais são mantidos pela prefeitura, o que motivou a não inclusão dos mesmos no supracitado projeto, segundo relato de um funcionário do Sistema Autônomo de Água e Esgoto - SAAE - de São Bento, e que hoje em dia trabalha na CASAL.

Levando-se em conta as características individuais do município e de seus povoados com processos de urbanização tão díspares, a concepção do projeto não permitiu resolver todas as fontes de esgoto que poderiam comprometer a balneabilidade no município. Essa é uma situação grave, pois como afirmam Lucas et al. (2011, p. 2) "[...] o esgoto não tratado pode 
prejudicar o meio ambiente e a saúde das pessoas. Os agentes patogênicos podem causar doenças como a cólera, a difteria, o tifo, a hepatite e muitas outras".

A área de abrangência do projeto contemplou apenas a área urbana da sede municipal de Maragogi e o povoado de Barra Grande. Mesmo na área urbana da sede municipal as casas do conjunto Tereza Verzeri e as unidades habitacionais de um dos maiores conjuntos de Maragogi, o Adélia Lira, também não foram contempladas com as obras do sistema de esgotamento sanitário do programa em discussão. No entorno das residências do Adélia Lira existia uma galeria de águas pluviais (Figura 4) que posteriormente foi transformada pelos moradores da região em esgoto a céu aberto, cujas águas deságuam diretamente no mar, de modo mais específico, na Rua Jangadeiros, no trecho final da orla de Maragogi, ao lado de uma pousada.

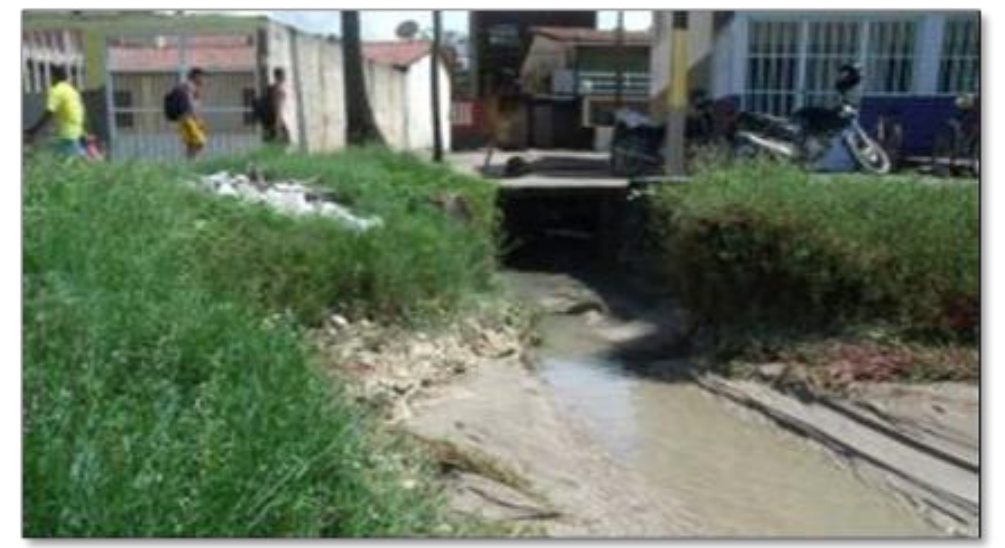

Figura 4: Galeria de águas pluviais transformada pelos moradores do Adélia Lira em esgoto - dejetos deságuam no trecho final da orla de Maragogi. Fonte: Lins (2015).

Figure 4: Rainwater gallery transformed by the residents of Adélia Lira in sewage - waste flow into the final stretch of Maragogi's seaside. Source: Lins (2015).

A justificativa para a ausência da implementação do programa nesta área foi porque o conjunto residencial Adélia Lira já havia sido contemplado com um sistema de saneamento instalado pela prefeitura, através da Funasa. Os reatores anaeróbicos deste sistema foram instalados, porém, nunca funcionaram por falta de mão-de-obra qualificada para sua devida operacionalização, segundo relatos de moradores locais. Nas primeiras visitas feitas à área, no ano de 2009, o biodigestor ainda estava no local, apesar de não funcionar. A montagem da Figura 5 mostra, na rua Fernando Paes, o caminho do extravasamento de uma rede troncal que passa pela rua, mas não coleta o esgoto da região. O esgoto vaza, entra em um bueiro e em seguida deságua no canal que a esta altura ainda não estava tamponado, juntando-se ao fluxo d'água até o mar. Nas últimas visitas feitas à área em 2015, contatou-se que os reatores foram transformados em sucata e todo o esgoto oriundo deste conjunto habitacional continua sendo direcionado ao canal que tem o mar como destinação final. Sem tratamento.

O jornal de maior circulação no estado, a Gazeta de Alagoas, em sua edição de 3 de março de 2013, trouxe uma matéria intitulada "Esgoto ameaça praias urbanas em Maragogi". Quando fala deste sistema municipal do Adélia Lira, a matéria contém o seguinte trecho: 
Se o sistema gerido pelo município já não funcionava, o da Companhia de Saneamento de Alagoas (CASAL) já nasceu deficitário: não cobre toda a cidade e logo se mostra ineficiente. É que ele foi gestado ainda na metade da década de 1990, dentro do Programa "Costa Dourada", mas só aprovado no novo milênio. Dessa forma, novas áreas urbanas que surgiram após a elaboração do projeto, não foram contempladas com a rede de saneamento, a exemplo do Conjunto Tereza Verzeri. E o pior: os tecnocratas do governo e os engenheiros das construtoras ignoraram um dos maiores conjuntos habitacionais de Maragogi, o Adélia Lira, conhecido como "Grota", onde mora o grosso da população econômica e socialmente fragilizada. Para os técnicos como existia outro sistema de saneamento supostamente em uso no conjunto (o da Funasa), não seria necessário expandir as obras do Prodetur até lá. (GAZETA DE ALAGOAS, 2013, p. C4).

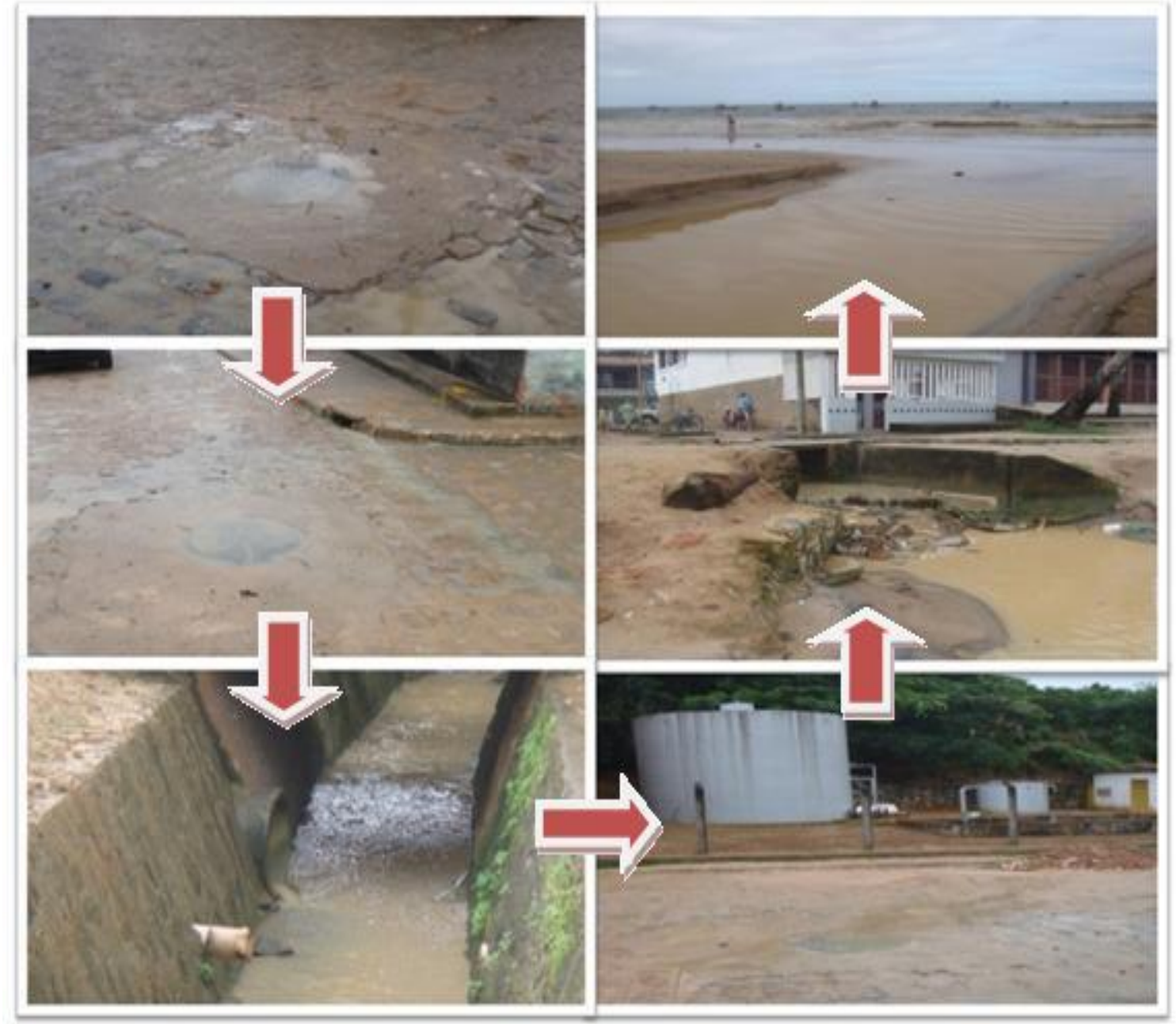

Figura 5: Esgoto correndo a céu aberto no conjunto habitacional Adélia Lira (Grota) desde o vazamento no poço de visitas, passando pela rede de drenagem urbana até o mar.

Fonte: Lins (2009).

Figure 5: Sewage running in the open set on the habitacional aggregation Adelia Lira (Grota) from the leaking well visits, through the urban drainage until to the sea.

Source: Lins (2009). 
Desde a primeira versão do projeto em 1995, até a última em junho de 1997, várias alterações foram feitas para o enquadramento às exigências não só do Prodetur/NE, como também do Banco do Nordeste do Brasil BNB (com interveniência do BID), o que acarretou em sua completa descaracterização.

As alterações foram feitas, porém a reavaliação financeira da obra também pesou muito. O projeto subdimensionou a expansão populacional e a demanda por infraestrutura, acelerada pelo processo de turistificação pelo qual o território passou nos últimos anos. Um morador antigo da orla (morador B) cita que "dia sim, dia não essas bueiras da CASAL vazam, deixando uma fedentina danada, espantando os turistas" (Figura 6). Os empreendedores da Avenida Senador Rui Palmeira (beira mar) reclamam que os extravasamentos são diários e a CASAL disponibiliza apenas um caminhão para esgotar a rede.

Portanto, para o atendimento de todas as exigências do BNB e do IMA, um novo projeto foi desenvolvido. Ressalta-se que este novo projeto teve duas revisões em 1997, sendo a última no mês de junho, com previsão de concretização de 20 anos, ou seja, apenas no ano de 2017. Sendo assim, a rede de esgotamento sanitário deveria estar funcionando a plena capacidade, atendendo a tudo o que foi proposto não só com eficácia, mas também eficiência, o que não tem sido o caso, pois são muitos os problemas identificados, evidentes desde a elaboração do projeto em si, algo que poderá ser identificado por meio das falas dos steakeholders ${ }^{2}$.

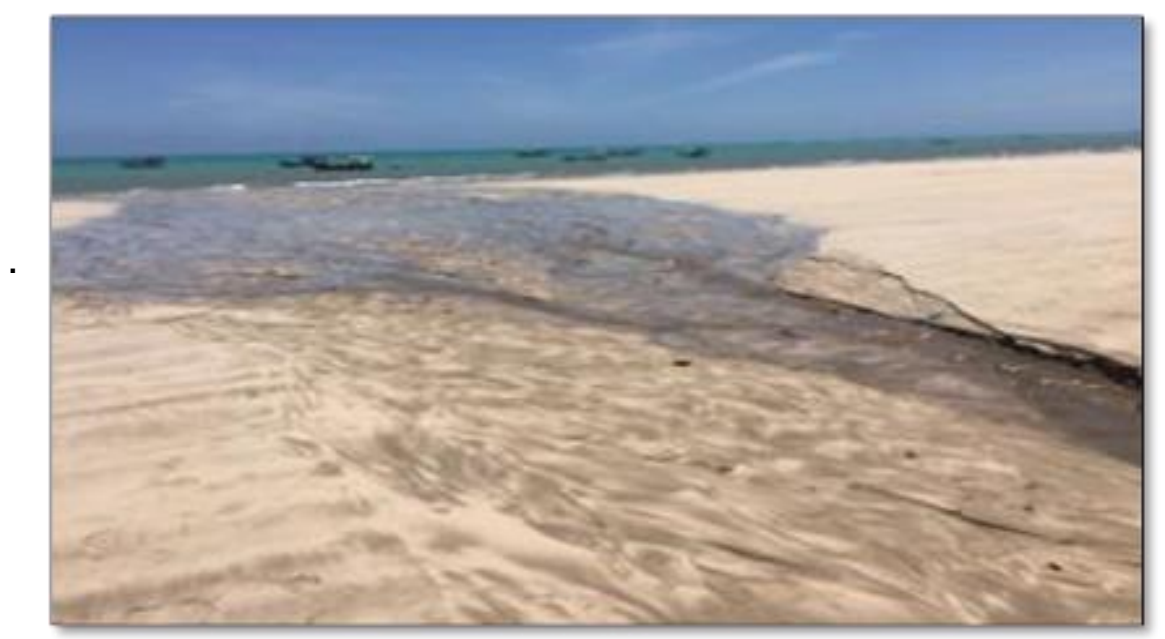

Figura 6: "Língua negra" na orla do centro urbano de Maragogi. Fonte: Lins (2015).

Figure 6: "Black tongue" on seaside of Maragogi's urban center. Source: Lins (2015).

O sistema foi ampliado e a rede coletora ficou maior. Antes eram $13.085 \mathrm{~m}$, passando para $20.240 \mathrm{~m}$, dos quais 8.460 em condomínios. As estações elevatórias de esgoto, que representam um grande gasto em obras físicas e em equipamentos para bombeamento, foram reduzidas de sete para quatro. Consequentemente, o número de sub bacias também caiu para quatro. Já no tocante à estação de tratamento, o sistema continuou o mesmo: Australiano com duas lagoas (aeróbica e facultativa) mais uma lagoa de maturação, sendo o tempo que os efluentes passam pelas lagoas 
aumentado de 12,3 dias para 21,3 dias o que garantiria uma maior eficiência no tratamento.

A área do projeto compreende uma estreita faixa costeira que vai do rio Maragogi, ao Sul, até Barra Grande, ao Norte, limitando-se a Oeste com a AL-101- Norte e a Leste com Oceano Atlântico abrangendo um total de 390 hectares (PROJETO TÉCNICO DO SISTEMA DE ESGOTAMENTO SANITÁRIO DO MUNICÍPIO DE MARAGOGI, ALAGOAS, 1997). Isso equivale a apenas $1,165 \%$ da área do município ou 3,9km². Com base neste dado, pode-se inferir que o referido projeto não contemplou nem $2 \%$ da área física total do município, apesar de concentrar $60 \%$ de sua população, deixando de fora, além dos locais já densamente povoados, como São Bento, toda a porção da margem esquerda da AL-101-Norte que corresponde a $95 \%$ do município.

As obras foram iniciadas em 2002, pela construtora Santa Bárbara. De início a Comunidade Ativa, programa federal criado entre os anos 1999 e 2000 que tinha por objetivo fomentar políticas públicas com inclusão social, acompanhou o projeto: como, aonde e para que seriam alocados os recursos, até mesmo dando opinião ativamente sobre tudo, como relatado em algumas entrevistas. Na fala da empreendedora A que também faz parte do poder público,

No início da Comunidade Ativa, ficamos muito animados com a possibilidade de acompanhar o projeto de saneamento aqui em Maragogi. Esse acompanhamento começou a ser feito com a participação de alguns membros da comunidade que fiscalizavam o andamento das obras. Quando começamos a pedir esclarecimentos sobre o aporte de recursos na obra e solicitar as notas fiscais dos materiais que estavam sendo usados, a coisa mudou de figura. Os líderes da Comunidade Ativa passaram a ser perseguidos e excluídos do processo, algo que gerou animosidades com os políticos locais (junho de 2015).

Logo depois, com a mudança de gestão a associação praticamente se dissolveu porque havia perseguição entre os líderes do processo. A falta de continuidade das políticas públicas em Maragogi é claramente percebida na maioria das falas dos steakeholders na cidade. Um morador (morador C) da cidade assim declarou a esse respeito, "[...] a cidade sempre esteve dividida entre dois grupos políticos, um de situação e outro de oposição. Quando um sai e entra o outro, tudo o que o primeiro fez é desfeito pelo segundo, por isso que essa cidade não vai para frente" (junho de 2015). São dois grupos políticos distintos, com ideais e projetos de poder idem, que divergem radicalmente e criam seguidores das duas vertentes. A percepção é que os projetos individuais sobrepõem-se aos coletivos causando uma distorção nas políticas públicas, com consequências negativas para a população e o meio ambiente, que ficam à mercê de políticas descontinuadas que não seguem uma linha única para um bem público. 
O cronograma inicial era para 18 meses de obra, até o fim de 2003, entretanto a obra arrastou-se até meados de 2005 com seus inúmeros contingenciamentos e falta de liberação de verbas.

A operação do saneamento, no entanto, estaria vinculada à conclusão da estação de tratamento de esgotos até fevereiro de 2005, que atrasaram, segundo a construtora, por causa das chuvas intensas na região durante o período.

No entanto, ainda houve outro problema que só foi constatado depois. No final das obras físicas do sistema em junho de 2005, viu-se que o bairro de Carvão já estava integrado ao centro urbano e precisava estar inserido na rede de esgotamento, assim como uma área de expansão no povoado Barra Grande. Foi elaborado um projeto complementar, datado de dezembro de 2005 e aprovado pela CASAL em janeiro de 2006, que contemplou o bairro de Carvão e parte de Barra Grande, tendo sido incluído no original como um anexo. Segundo consta nesse anexo, era um complemento de rede nestas localidades com $1.850 \mathrm{~m}$ para atender 26 casas do bairro Carvão e 45 do povoado Barra Grande, atendendo a uma população estimada em apenas 335 habitantes (PROJETO TÉCNICO DO SISTEMA DE ESGOTAMENTO SANITÁRIO DO MUNICÍPIO DE MARAGOGI, ALAGOAS, 2005, p.10).

Desta forma, conclui-se que o projeto em análise possui problemas sérios dos mais diversos tipos e que se agravaram com o passar do tempo, e com o crescimento da população, sobretudo nas áreas ambientalmente frágeis. Do projeto inicial em 1995 ao aprovado em 1997 e à implantação definitiva só em 2006 as lacunas foram muitas, mas uma das principais diz respeito à área de abrangência do projeto. Não seria possível ter uma solução definitiva para os problemas ambientais sem a construção de redes coletoras em todas as localidades já espacialmente identificadas, além de soluções, mesmo que paliativas para os pequenos assentamentos na área não litorânea. O Plano Diretor de Maragogi (2004) em seu artigo 55ำ cita em um dos subitens que o Plano de Saneamento da Cidade de Maragogi deve "[...] tornar obrigatória a implantação de unidades compactas de tratamento de esgoto para locais que não sejam atendidos pela rede pública de esgotos". Nada disso foi implementado e a própria empresa responsável pelo projeto reconhece que "[...] povoados como São Bento estão de fora". Os índices de balneabilidade continuam apontando as principais praias ao longo dos $21 \mathrm{~km}$ de litoral como impróprias, e, na fala de um morador $\mathrm{D}$, que é pescador em São Bento essa preocupação é latente:

Aqui não temos esgoto, é tudo lançado no mar de onde eu tiro o peixe que alimenta meus filhos. Os governos nunca se preocuparam conosco, nem quando colocaram os canos de esgoto na cidade aqui teve, porque não somos da CASAL. Aqui é muito bonito e bom de morar, mas falta governo pra cuidar (julho de 2015).

Outros relatos semelhantes foram registrados. Os empreendedores reclamam que sem a paisagem natural preservada não há turista, e a maioria reclama das condições da praia. Um dono de pousada mais

291 Revista Brasileira de Ecoturismo, São Paulo, v.10, n.2, mai-jul 2017, pp. 270-299. 
afastada do centro urbano, e próxima à foz do rio Persinunga, desabafa (empreendedor B):

\begin{abstract}
Para os meus hóspedes eu monitoro semanalmente a balneabilidade em frente ao meu estabelecimento que fica afastado do centro, mas mesmo assim apresenta índices de contaminação alarmantes. Eu tenho vergonha quando tenho que pedir a pessoas que pagaram caro e vieram de tão longe que usem só a piscina porque o mar está praticamente um esgoto. Eu tenho soluções de tratamento de esgotos e resíduos sólidos na minha pousada, mas infelizmente nem a população nem o governo faz sua parte. Procuro não levar meus hóspedes ao centro pois eles sempre relatam que a região é muito "feia" e caótica e tem esgoto a céu aberto. O hóspede quer mar, se não pode tomar banho, ele não volta (junho de 2015).
\end{abstract}

Esse relato demonstra o sentimento latente em muitas pessoas na região, em relação aos problemas de balneabilidade do mar costeiro em Maragogi. Falta iniciativa ao poder público em elaborar e implementar políticas eficazes para minimizar os problemas da sociedade local e também colaboração de uma parcela grande dos nativos que degradam o meio ambiente de forma ininterrupta.

\title{
Múltiplas visões sobre o saneamento em Maragogi
}

Esta parte do artigo relata primeiramente as percepções dos 31 entrevistados dentre os moradores locais. Para 55\% dos entrevistados a vida mudou de forma substancial com a chegada dos turistas ao município, tendo em vista que houve a ampliação do comércio com a chegada de novos empreendimentos, o que por consequência propiciou a geração de mais emprego e renda para a população local. As percepções dos entrevistados corroboram o entendimento de Carvalho (2015, p.83) de que "[...] o turismo é o meio e não o fim, pois com o aumento do número de visitantes a cidade movimenta a economia, impactando dezenas de atividades e promovendo o desenvolvimento econômico e social, gerando emprego e renda".

Quando questionados se algo precisava ser melhorado para atender a população e os turistas que visitam a localidade, $90 \%$ dos entrevistados pontuaram que muito precisa ser melhorado não só em relação ao atendimento das necessidades da população local quanto daqueles que no território estão de passagem. Nesta perspectiva, os entrevistados sinalizaram a necessidade de melhoramento da infraestrutura local, o que envolve toda a orla, ampliação de postos de saúde, qualificação da mão de obra da localidade para melhor atender o turista, além da necessidade de outras atrações que não exclusivamente a praia.

Quando perguntados se residiam na cidade quando da implantação do projeto da rede de esgoto, $70 \%$ deles afirmaram que sim, no entanto, $48 \%$ disseram que não houve qualquer tipo de divulgação sobre o projeto 
junto à população. Um dos respondentes que muito colaborou com os resultados da pesquisa, por ter trabalhado na obra do projeto em questão, afirmou que mesmo ao ter conhecimento da implantação da rede de esgotos em áreas específicas do município, uma parcela importante da população não se interessou em aderir ao projeto.

Para $61 \%$ dos entrevistados, a rede coletora de esgotos da CASAL passa em frente a casa deles, e destes, $95 \%$ esta interligado. Muitos relataram que quando da implantação do projeto, as obras destruíram boa parte das ruas e a cidade virou um caos por dois anos. Quando pronta, a interligação à rede coletora de esgotos foi outro processo caro e demorado. Segundo a fala de alguns moradores, eles tiveram que fazer obras dentro das residências o que se tornou oneroso. Foi por este motivo que a adesão foi baixa no início, apenas quem podia pagar pela ligação e pelas obras que ela demandava o fizeram em tempo hábil.

Nesta perspectiva, foi identificado um total descaso por parte dos políticos locais e da prestadora do serviço, tendo em vista que o planejamento deveria ser feito para todas as etapas, desde a implantação do projeto (obras) até sua operacionalização, que, na verdade, é a parte mais importante, uma vez que sem ligação à rede coletora não há esgoto a ser coletado. E sem coleta, mesmo que seja de apenas uma residência em uma rua por onde passe a rede, o fim dos dejetos do esgoto sempre será os corpos d'água e, consequentemente, o mar, algo que foi observado quando das pesquisas in loco.

Por fim, ainda no escopo dos moradores locais, para $80 \%$ dos entrevistados a qualidade do meio ambiente de Maragogi é ruim ou regular, sendo perceptível em sua própria fala a falta de consciência da população local ao jogar lixo nas ruas e ao não realizar a conexão da rede de esgotos de suas moradias a rede coletora de esgotos, enfim, ao contribuir para um ambiente cada vez mais poluído, e não cuidar do seu próprio local de moradia, uma vez que para $67 \%$ dos entrevistados, as praias de Maragogi são poluídas exatamente pela população local destinar boa parte dos dejetos de seus esgotos ao mar.

Dos 30 turistas entrevistados, $25 \%$ eram entrevistados foram estrangeiros e $75 \%$ provindos do próprio país, que tiveram em sua maioria 0 ócio, a recreação ou as férias como o motivo principal de sua visita $(90 \%)$, vindo em busca da beleza das praias e paisagens exuberantes do destino Maragogi. A maioria considerou a experiência geral vivida em sua estadia boa ou excelente (64\%), apesar de muitos terem expressado insatisfação quanto à falta de profissionalização do atendimento oferecido na localidade. Além da beleza das praias, a gastronomia foi citada por $60 \%$ dos entrevistados com sendo boa ou excelente, sobretudo os frutos do mar e os biscoitos de goma, popularmente chamado de sequilhos.

Apesar de $100 \%$ dos entrevistados terem dito que recomendariam o destino para amigos e familiares e que pretendiam voltar, os problemas ambientais sobressaíram na experiência geral vivida pelos turistas em sua estadia. A fala da maioria era que a localidade tem algumas das paisagens mais lindas já vistas, porém falta preservação e saneamento (70\%), o que compromete os recursos naturais para gerações futuras. Outro problema 
percebido foi à falta de diversidade e qualidade dos atrativos culturais (73\%), sobretudo noturnos, apesar de reconhecerem a riqueza e a criatividade do artesanato local.

Por fim, a expectativa da maioria dos turistas foi atendida $(60 \%)$ e os que não ficaram satisfeitos deixaram claro que foi por razões de falta de preservação do meio ambiente, o que corrobora o observado na pesquisa, onde, apesar de uma intervenção que visava solucionar os problemas ambientais do município, estes não funcionaram a contento.

Todos os 12 gestores públicos e empreendedores entrevistados foram unânimes em afirmar que a chegada dos turistas mudou a vida da localidade uma vez que gerou mais emprego e renda. No entanto, o processo de turistificação do município também gerou a percepção de crescimento desordenado (92\%) e problemas de meio ambiente na localidade (100\%). Apesar de $85 \%$ dos entrevistados participarem de alguma atividade ligada ao turismo, sobretudo nos ramos de hotelaria e agenciamento, $80 \%$ deles concordam que algumas coisas precisam melhorar para atender não só os turistas mas também a população local. Os principais problemas citados são de infraestrutura, nela incluída a falta de saneamento básico em grande parte do município, a falta de políticas públicas consistentes, atrações turísticas que não sejam as praias e a capacitação e investimentos em mão de obra local.

O turismo é a maior fonte de renda local, porém grande parte da população local não entende a importância da atividade na economia do município. Essa fala, percebida em toda a pesquisa, foi uma constante em mais da metade dos entrevistados (55\%) e denota a possível falta de interesse na participação popular, nas raras vezes que a população é convocada a participar. Apesar disso, metade dos entrevistados concorda que o turismo contribui para a preservação do meio ambiente uma vez que conscientiza uma parcela de moradores e turistas e orienta para a preservação dos recifes de corais.

No entanto, a grande maioria (83\%) considera a qualidade do meio ambiente em Maragogi ruim ou péssima e que o turismo tem uma parcela importante de culpa em relação ao problema. Outro dado importante coletado nas entrevistas $(65 \%)$ foi que a própria população não tem consciência ambiental e polui o meio ambiente de forma sistemática, seja com o descarte de resíduos sólidos em locais inapropriados ou com o lançamento de esgotos nas ruas, mesmo em locais onde a rede coletora de esgoto passa em frente a casa deles. Estes dados mais uma vez sugerem que a intervenção realizada no território, com o objetivo de resolver os problemas de saneamento, não foi à altura das dificuldades locais, sendo insuficiente para resolver os problemas ambientais no município. 


\section{Conclusões}

Análises realizadas em setembro de 2015, pelo IMA, apontaram que cinco praias de sete com coletas realizadas no município de Maragogi, encontravam-se impróprias para banho. Para piorar, em três delas o Número Mais Provável de coliformes termotolerantes fecais por cada 100 mililitros $(\mathrm{Nmp} / 100 \mathrm{ml})$ de amostra coletada era superior a 16.000 (dezesseis mil unidades), o que é considerado esgoto in natura. Esses locais eram um trecho da orla urbano, em frente à Praça Multieventos, no centro da sede do município, e a foz dos rios Persinunga e Salgado.

O saneamento ambiental, por ser um dos principais vetores da sustentabilidade, surge como um pilar central para construção de um ambiente em que o desenvolvimento sustentável possa caminhar junto a interesses voltados à lógica capitalista do lucro, para que nenhum se sobreponha ao outro e as soluções 'verdes' ajudem a preservar o meio ambiente natural da localidade.

No entanto, se constata com esse estudo que mesmo após a implantação de um projeto de saneamento em Maragogi, entre as décadas de 1990 e 2000, o município continua a sofrer graves problemas ambientais relacionados ao esgoto sanitário, que degradam o meio ambiente e a paisagem local, recurso de alta importância para uma das mais importantes atividades turísticas, o turismo. $O$ estudo identificou que o referido projeto não contemplou todo o município, abrangendo menos de $2 \%$ de seu território, deixando várias fontes de esgoto fora de seu alcance, o qual tem como destinação seus corpos d'agua e posteriormente o mar.

Os recursos naturais de Maragogi e a paisagem são o principal motivo da venda da localidade como 'paraíso das águas', sendo considerada uma das principais destinações de "sol e mar" do país. Contudo, os impactos negativos do processo de turistificação local, bem como da dinâmica urbana de crescimento acelerado sem planejamento adequado, levaram seu território a uma problemática situação de degradação ambiental que representa um ônus real muito grande para a população local.

Para que seja possível ocorrer uma transformação plausível e sustentável é preciso haver planejamento e inclusão. No entanto, nas entrevistas com pessoas da população local, turistas, empreendedores e técnicos que trabalham para o governo municipal, percebeu-se que a visão dos planejadores ainda é muito física, restringindo-se à infraestrutura e às acomodações, em detrimento do meio ambiente, da sociedade, da economia regional e de outros aspectos locais. Para um bom planejamento a longo prazo que contemple, sobretudo, um desenvolvimento sustentável e não apenas um crescimento imediato, alguns vetores precisam ser amplamente avaliados e validados pela população local que precisa ser instada a participar e capacitada para isto. Para tanto, as políticas devem ser inclusivas e contar com ampla participação popular através de mecanismos que assegurem, não só voz, mas também participação direta no processo de tomada de decisão na formulação das políticas públicas. 


\section{Referências}

ARAUJO, L.M. Internacionalização turística de regiões periféricas emergentes: questões centrais para o litoral de Alagoas. Latitude, ano 1, n.1, p.103-119, Maceió, 2007.

BARROS, M.V. A contribuição da participação sociopolítica para o desenvolvimento do turismo sustentável no município de Maragogi, Alagoas. 2005. 208f. Dissertação (Mestrado em Desenvolvimento e Meio Ambiente) - Universidade Federal de Alagoas, 2010.

BENI, M.C. Política e planejamento de turismo no Brasil. São Paulo: Aleph, 2006, p. 63.

BOULLÓN, R.C. Planejamento do espaço turístico. Tradução Josely Vianna Baptista. Bauru, SP: EDUSC, 2002.

CARIBE NORDESTINO. Vista aérea do município de Maragogi em sua porção Sudoeste. Disponível em: <http://caribenordestino.com.br>. Acesso em: 12 dez. 2015.

CARVALHO, R. Minha doença é crônica. Joinville, SC: Clube dos Autores, 2015.

CARVALHO, S. Esgoto ameaça praias urbanas em Maragogi. 2013. Disponível em: <http://gazetaweb.globo.com/portal/noticiaold.php?c=335396\&e=14>. Acesso em: 4 out. 2015.

CASTRO, I.E. Paisagem e turismo: de estética, nostalgia e política. IN: YÁZIGI, E (Org.). Turismo e paisagem. São Paulo: Contexto, 2002.

CRUZ, R.C.A. Introdução à geografia do turismo. 2. ed. São Paulo: Roca, 2002.

ENCICLOPÉDIA DOS MUNICÍPIOS ALAGOANOS. 2010. Disponível em: $<$ http://www.youblisher.com/p/525211-Enciclopedia-dos-Municipios-de-

Alagoas/>. Acesso em: 10 nov. 2015.

GONÇALVES, L.B. Turismo e sustentabilidade cultural no município de Maragogi: um estudo de caso. 2001. 135 f. Dissertação (Mestrado em desenvolvimento e meio ambiente) - Universidade Federal de Alagoas, Maceió, 2001.

GOOGLE EARTH. Vista aérea e satélite do município de Maragogi, suas principais praias e rios Maragogi, Salgado e Persinunga e povoados de Peroba e Ponta do Mangue. Disponível em: <http://www.googleearth.com.br>. Acesso em: 14 dez. 2015.

HALL, C.M.; PAGE, S.J. The geography of tourism and recreation: environment, place and space. London: Routledge, 1999.

HOTEIS BEIRA MAR. Piscina natural Galés de Maragogi. Disponível em: $<$ http://hoteisbeiramar.com.br $>$. Acesso em: 18 dez. 2015.

INSTITUTO BRASILEIRO DE GEOGRAFIA E ESTATÍSTICA - IBGE. Censo 2010. Disponível em:<http://www.ibge.gov.br>. Acesso em: 20 dez. 2014.

INSTITUTO BRASILEIRO DE GEOGRAFIA E ESTATÍSTICA - IBGE.Censo 2015. Disponível em:<http://www.ibge.gov.br>. Acesso em: 10 mar. 2016. 
KASPARY, M.G.A.R. O desenvolvimento local e o desenvolvimento turístico do município de Maragogi, Alagoas. 2012. Dissertação (Mestrado em Arquitetura e Urbanismo: Dinâmicas do Espaço Habitado) - Universidade Federal de Alagoas. Faculdade de Arquitetura e Urbanismo. Maceió, 2012.

KÖRÖSSY, N. Do turismo predatório ao turismo sustentável: uma revisão sobre a origem e a consolidação do discurso da sustentabilidade na atividade turística. Caderno virtual do turismo. Rio de Janeiro, v.8, n.2. 2008. P. 56-58.

LIMA, T.F.; LOPES, G.E.V. Percepção de diferentes grupos sociais sobre o ordenamento da exploração turística das piscinas naturais de Maragogi. 2014. Disponível em: $<$ http://www.pasosonline.org/Publicados/12114/PS0114 04.pdf>. Acesso em: 10 dez. 2014.

LOURENÇO, A.G.; SCHOEDER, D.S. Vale investir em responsabilidade social empresarial stakeholders, ganhos e perdas. Disponível em:<http://institutoguerreiros.com.br/docs/VALE\%20INVESTIR\%20EM\%20R ESPONSABILIDADE\%20SOCIAL\%20EMPRESARIAL.pdf>. Acesso em: 10 out.. 2015.

LUCAS, M.; MEDEIROS, S.A.; MARTINS, R.R.; DUTRA, T.F. Tratamento dos esgotos, a medida de amenização de diversos problemas ambientais urbanos. 2011. Disponível em: $<$ http://www.eumed.net/rev/cccss/11//mmd.htm>. Acesso em: 10 nov. 2015.

MAGALHAES, C.F. Diretrizes para o turismo sustentável em municípios. São Paulo: Roca, 2002.

MARCONI, M.A.; LAKATOS, E.M. Fundamento da metodologia científica. 7. ed. São Paulo: Atlas, 2010.

MARICATO, E. Brasil, cidades: alternativas para a crise urbana. Petrópolis: Vozes, 2001.

MASCARENHAS, S.A. Metodologia científica. São Paulo: Pearson Education. Brasil, 2012.

MINAYO, M.C.S. O desafio do conhecimento:pesquisa qualitativa em saúde. São Paulo: Hucitec, 2007.

MINISTÉRIO DO TURISMO. Índice de competitividade do turismo nacional: 65 destinos indutores do desenvolvimento turístico regional. Ouro Preto, 2011.

MONTE, B.E.O.; SANTOS, R.C.A.Lima. Análise temporal da balneabilidade das praias do município de Maragogi. Anais do XIX Simpósio Brasileiro de Recursos Hídricos. Maceió/AL. 2015. Disponível em: $<$ http://www.abrh.org.br/sgcV3/index.php?PUB=3\&ID=81\&PAG=3>. Acesso em: 12 nov. 2015.

NEVES, R.C. Discussão de assuntos complexos na visão de professoras e alunos. Jundiaí: Paco, 2014.

ORGANIZAÇÃO MUNDIAL DE TURISMO - OMT. Guia de desenvolvimento do turismo sustentável. Porto Alegre: Bookman, 2003. 
PALMEIRA, M.V.L. Desenvolvimento urbano e turismo: uma análise da dinâmica urbana em Jequiá da Praia, Alagoas. Dissertação (Mestrado em Arquitetura e Urbanismo: Dinâmicas do espaço Habitado) - Universidade Federal de Alagoas, Faculdade de Arquitetura e Urbanismo. Maceió, 2007.

PIRES, P.S. Dimensões do ecoturismo. São Paulo: Senac, 2002.

PREFEITURA MUNICIPAL DE MARAGOGI. Plano Diretor de Desenvolvimento Sustentável - PDDS, dezembro de 2004.

PROJETO TÉCNICO DO SISTEMA DE ESGOTAMENTO SANITÁRIO DO MUNICÍPIO DE MARAGOGI-AL. Vol. 1 - UNIDADE EXECUTORA ESTADUAL DO PRODETUR/AL, jun. 1997.

RUSCHMANN, D.V.M. Impactos ambientais do turismo ecológico no Brasil. Turismo em análise. São Paulo, v.4, n. 1, p. 56-68, maio 1993.

RUSCHMANN, D.V.M.; WIDMER, G.M. Planejamento turístico. In: ANSARAH, M.G.R. (Org.). Turismo: como aprender, como ensinar. São Paulo: Senac, 2001, p. 65-86.

SANCHO, A. Introdução ao turismo. São Paulo: Roca, 2001, p. 201.

SANTOS, M. Metamorfoses do espaço habitado: fundamentos teóricos e metodológicos da geografia. 5. ed. São Paulo: Hucitec, 1997.

SETUR Secretaria de Turismo de Alagoas, Planos de Investimentos 2008. Disponível em: <http://www.turismo.al.gov.br>. Acesso em: set. 2010.

SISTEMA NACIONAL DE INFORMAÇÕES SOBRE SANEAMENTO - SNIS. Informações sobre saneamento do município de Maragogi 2006. Disponível em: <http://snis.gov.br>. Acesso em 14 dez. 2015.

SOARES, S.R.A.; BERNARDES, R.S.; CORDEIRO NETTO, O.M. Relações entre saneamento, saúde pública e meio ambiente: elementos para formulação de um modelo de planejamento em saneamento. Cadernos de Saúde Pública. Rio de Janeiro, v. 18, p. 1713-1724, 2002.

SONAGLIO, K.E.; FABBRIS, C. Turismo: reflexões e desafios de um fenômeno contemporâneo. São Paulo: Livrus, 2012.

SOUZA, G.S.; SANTOS, A.R.; DIAS, V.B. Metodologia da pesquisa científica: construção do conhecimento e do pensamento científico no processo de aprendizagem. São Paulo: Animal, 2013.

TONETO JUNIOR, R. A situação atual do saneamento básico no Brasil: problemas e perspectivas. 2004. 324 f. Tese (livre-docência em economia) Faculdade de Economia, Administração e Contabilidade, Universidade de São Paulo, São Paulo, 2004, p. 31.

TÖPFER, K. Keynote Speech. Launch of the UNEP/SETAC Life Cycle Initiative, UNEP. Prague, 2002.

VISITE MARAGOGI. Atrativos turísticos. Disponível em: <http://www.visitemaragogi.com>. Acesso em 15 dez. 2015.

YAZIGI, E. Civilização urbana, planejamento e turismo: discípulos do amanhecer. São Paulo: Contexto, 2003. 


\section{Notas}

${ }^{1}$ Resguardando o sigilo exigido pelo comitê de ética, os entrevistados serão identificados neste artigo apenas pelo tipo (morador, turista, empreendedor, gestor), seguido de uma letra, com data (mês e ano) que a entrevista foi realizada.

${ }^{2}$ Refere-se a um grupo de pessoas (partes interessadas) que dentro ou fora da organização possui interesse no desempenho da mesma, de acordo com Lourenço e Schroder (2015).

${ }^{3}$ Trabalho derivado da dissertação submetida ao programa de Mestrado em Dinâmicas do Espaço Habitado, da Universidade Federal de Alagoas (UFAL), para obtenção do grau de Mestre.

Antônio de Padua Gomes D'Almeida Lins: Universidade Federal de Alagoas, Maceió, AL, Brasil.

E-mail: apgdl@uol.com.br

Link para o currículo Lattes: http://lattes.cnpq.br/4995139995571077

Lindemberg Medeiros de Araújo: Universidade Federal de Alagoas, Maceió, AL, Brasil.

E-mail: Imedeirosbr@gmail.com

Link para o currículo Lattes: http://lattes.cnpq.br/1427075376799452

Walter Matias Lima: Universidade Federal de Alagoas, Maceió, AL, Brasil.

E-mail:waltermatias@gmail.com

Link para o currículo Lattes: http://lattes.cnpq.br/0941145152986197

Data de submissão: 29 de agosto de 2016

Data de recebimento de correções: 05 de maio de 2017

Data do aceite: 05 de maio de 2017

Avaliado anonimamente 